\title{
Teacher Professionalism Training Program as a Solution for Teacher Problems
}

\author{
$1^{\text {st }}$ Alan Sigit Fibrianto \\ State University of Malang \\ Indonesia \\ alan.sigit.fis@um.ac.id
}

\author{
$2^{\text {nd }}$ Ananda Dwitha Yuniar \\ State University of Malang \\ Indonesia \\ ananda.dwitha.fis@um.ac.id
}

\begin{abstract}
Teacher professionalism training program or in Indonesia called PPG is one of the government programs in improving teacher competency in Indonesia. At present, to become a teacher is required to have a teaching certificate issued from the participation of prospective teachers in PPG activities. This activity is expected to be able to create professional educators both in the formation of teacher character and mastery of scientific fields. This study aims to explain how PPG can answer the problems of teacher professionalism. The researcher used qualitative methods with a conceptual approach to the concept of A.G.I.L. (Adaptation, Goal Attainment, Integration, and Latency) as the analysis. The results show that there are still several problems such as: (1) unclear information about PPG; (2) knowledge of prospective educators who are still lacking in PPG; (3) availability of human resources as a teacher of PPG; (4) there is a polemic related to the portion for prospective PPG participants who are not only accepting from education graduates; (5) the disappearance of one of the PPG programs, namely SM3T (Bachelor of Teaching in the Leading, Outermost, and Disadvantaged Areas) as a result of the change of leaders that affected the change of policy, which should have been perfecting existing programs; (6) the need for a conceptual approach to A.G.I.L. from Talcott Parsons to be able to answer the PPG problem in education.
\end{abstract}

Keywords: education, teacher professionalism training program or PPG, A.G.I.L.

\section{INTRODUCTION}

Based on Republic of Indonesia Law Number 20 of 2003 concerning the national education system [1] followed by Republic of Indonesia Law Number 14 of 2005 concerning Teachers and Lecturers (UU-GD) [2] and Republic of Indonesia Government Regulation Number 19 of 2005 concerning National Education Standards (PP-SNP) [3], conceptually and empirically requires adjusting the level of policy that will be used as a reference for compiling various programs, including teacher education. The teacher is one functional office where almost all levels of society have recognized the existence of the teacher as an educator. The Teacher Professional Education Program (PPG) is an educational program that is given to undergraduate or diploma 4 graduates so that they can produce prospective teachers who have the ability to realize the goals of national education. The Teacher Professional Education Program (PPG) is also carried out to be able to improve the competencies of prospective teachers. In addition to PPG, the government has other programs to accelerate education development. The program was implemented to be able to help the development of education in remote, outermost and disadvantaged areas, known as the PPG-SM3T program [4].

At present, to become a teacher is required to have a teaching certificate issued from the participation of prospective teachers in PPG activities. Whereas before, prospective teachers from the LPTK (Teacher Training Education Institution) graduates when they graduated, they will be disgusted with the name Akta IV, which is a certificate for prospective teacher graduates who can be used to become educators in educational institutions throughout Indonesia. However, the existence of Akta IV has now been abolished and replaced with a teaching certificate that will be given by prospective educators after following and graduating in a new program from the government called the Teacher Professional Education (PPG). Then from the PPG a new program was also launched aimed at fresh graduates or recent graduates of the Higher Education Institution called the Undergraduate Teaching Program in the Leading, Remote and Outermost areas, or abbreviated as SM3T. Then, how then can PPG with SM3T answer the problem of teacher professionalism? And to what extent can the program overcome the problem of education in Indonesia? Some of these are big questions in the discussion of this article.

\section{METHOD}

This study uses qualitative methods with a qualitative descriptive approach in looking at educational phenomena with teacher professionalism training program in Indonesia. Qualitative research is an active process that expresses logically, systematically and empirically the social phenomena that occur around to be reconstructed to reveal the truth that is 
beneficial to the life of society and science. The truth in question is the order that creates security, order, balance, and welfare of the community [5]. According to Miles and Huberman [6], qualitative research is more or less analogous to the investigation process, not much different from the work of detectives who must get an overview of the particular phenomenon being investigated. Kirk and Miller [7] define qualitative research as a particular tradition in social science that is fundamentally dependent on human observation in its own region and in contact with these people. Bogdan and Tylor [8] propose qualitative research methods as research procedures that produce data descriptions in the form of written or verbal words from people and observed behavior. This study attempts to explain social phenomena in the realm of education, especially about the teacher professionalism training program in Indonesia. This paper describes sociological arguments for existing educational phenomena related to becoming a professional teacher.

\section{RESULT AND DISCUSSION}

\section{A. The Role of Teacher Professionalism Training in Answering Teacher Problems}

The previous section has explained what the PPG program is and also what is the SM-3T program that is part of PPG. The aim of the program is none other than not to print Indonesian teachers who are professional and competent in their fields [9]. Many steps are taken by the government to produce professional educators. PPG and SM-3T are among the many programs from the government that aim to improve teacher professionalism. The beginning of PPG's presence in the midst of the community was welcomed with various pros and cons. [10] quoted in the kompasiana.com column dated June 17, 2015 with the title "PPG, Pros and Cons for Students of the Department of Education", the article said from two perspectives namely, pros and cons. In the pro part, this training can make teacher education graduates more professional and more mature in teaching, besides that in this training can also increase the quality of teachers in terms of learning planning and teacher management, as well as obtaining certification after training so that it will make the teacher's career more prosperous in educating and educating the nation's children. On the other hand, the contra part is seen from the government program which requires that everyone who will become a teacher be educated with a four or a bachelor degree (S1). The time taken by the first level is four years, certainly not a short time especially to study various teacher education theories and their compulsory practices. Judging from the PPG plan, it is possible that the government or relevant agencies that want to hold this training assume that the education level of the teacher education department is not enough to make graduates become qualified and professional teachers. If that is the case, it means that the 4-year requirement for tertiary education that is required to become a teacher is only the main requirement, and PPG is a condition that has not been revealed.

Besides that, PPG is also not only intended for S-1 graduates of Education, but also opens opportunities for NonEducation S-1/IV graduates. That way, this adds to the number of quota of competitors who will take part in the PPG program. There is also the assumption that this is an inequality when viewed from the registrant's basics. For graduates of S-1 Education who in fact have learned about the basics of teacher professionalism for 4 years must compete again with graduates of S-1/D IV Non-Education in addition to other S-1 graduates of Education. If S-1/D IV Non-Education can compete in the selection of candidates for PPG participants, then the PPG program is an instant step for S-1/D IV Non-Education graduates who have a pure science base to become a teacher and even as a professional teacher.

Previously, an undergraduate graduate of Education got his name as Deed IV or teaching certificate. That is, by pocketing Deed IV, graduates of S-1 Education can use it to become educators in educational institutions throughout Indonesia because by having Deed IV means S- 1 graduates can become teachers. However, the existence of Act IV has now been lost because it has been abolished, and there is a new policy from the government that to become a teacher must take part in the Teacher Professional Education (PPG) program. This also applies to those who have Deed IV. PPG is a new policy to change the system that previously existed in relation to teacher recruitment and aims to produce professional teachers. So, for S-1 graduates who want to become teachers are required to take part in the PPG program. In addition, by participating in the PPG program, the graduates will get an additional degree behind S.Pd, namely Gr, which means that for those who have taken the PPG program and graduated, their degrees are, S.Pd, Gr. That, indicates that they are officially recognized as professional teachers and already have teaching certificates.

In addition, there is also a PPG scholarship program for fresh graduates or students who have just graduated from the $S$ 1 Education Program, namely by attending the SM-3T. Bachelor of Teaching in the Foremost, Outermost, and Disadvantaged areas or abbreviated as SM-3T, is one of the programs devoted to those new graduates from S-1 Education. The length of time students take PPG - SMT 3T, which is for 2 years, consists of the first year required teaching services in the $3 \mathrm{~T}$ area, and after that in the second year also required to participate in the implementation of PPG activities funded by the government.

The aim of increasing teacher professionalism is inseparable from various polemics and pros and cons. This is due to many different perceptions among the community in response to PPG. Perceptual differences occur by one of the factors, namely, the lack of detailed and straightforward information about the PPG program that was recently 
launched, although in its implementation it has scored 5 generations since 2011 which is the first batch. The lack of socialization related to what PPG is, what is SM-3T, how is the ins and outs of the program, why is this required, what distinguishes the previous program, what are the requirements to participate in PPG, how steps should be taken to follow PPG for students who have just graduated from undergraduate education who want to teach or become teachers who are categorized as professional teachers, what type of PPG can be followed in accordance with the fields involved, what benefits are obtained by participating in the PPG program, and various information related to PPG and SM programs -3T. Information dissemination is very necessary because it is important to remember that the program is required for prospective teachers, so it would be nice if the information related to this was conveyed since students were on the lecture bench, so they could determine what next steps they would take to pursue the desired target. And even if there is a need for consultative forums that can accommodate the aspirations of students related to various things that become the unity of students both in terms of lectures, as well as related prospects in the future that have started to be designed early, that is when they are in college. For example, in high school/MA/SMK that have BK subjects (Counseling Guidance), therefore in Higher Education, especially in each study program should have counseling programs as well as those implemented in SMA/MA/SMK, so that aspirations students can be channeled and answer the problems faced by students. This is also expected to be useful to minimize the anarchic actions of students who feel their aspirations are not maximally channeled. Maybe in some study programs already have BK (Counseling Guidance) courses, but there are still many study programs that have not implemented them, and even if there are these courses, the implementation of the lecture process is still far from what is expected, and feels less accommodating for each student's aspirations. Therefore, a special curriculum may be needed to regulate related subjects with the aim of creating a forum for consultation and information delivery. That way, the discourse is expected to help the institution in this case the Higher Education can touch every student in terms of information and delivery of aspirations. It is hoped that between the government, universities, with students can establish good synergy, without miscommunication. In the end, socialization is needed so that information can be conveyed properly and maximally, especially in the example of this paper, which concerns PPG and SM-3T.

Then, if it has been implemented properly, then the need to maintain and if necessary improve so that everything can be aligned. If it is associated with the structural functionalism theory of Talcott Parsons, he presents one of his well-known concepts, namely, with the concept of A.G.I.L. Where A.G.I.L stands for (A) Adaptation, (G) Goal attainment, (I) Integration, and (L) Latency [11]. [12] stated in his research about the role of an institution's program that is inseparable from the involvement of several actors in it, runs structurally in a system, and synergizes with one another to achieve goals.

The need for Adaptation, in this case every new policy is needed to make habituation so that it becomes commonplace and accustomed. Adaptation can also be interpreted as an adjustment to something. With the implementation of a particular system or the implementation of a particular policy, one of the first steps that must be applied is by adapting, trying to adjust to the system or policy and adjusting to the existing culture, then with this habituation process, individuals can adapt to good and able to accept something that is either new or pre-existing.

In addition, the implementation of a particular policy or system must have the intent and purpose to be achieved or agreed upon together. So, in this case each application of a particular policy or system has a goal achievement. There is a final goal or final goal that becomes a common priority, there is the hope of creating a common consensus, so that the goals that are aspired will be well realized through a process carried out together.

In the context of the discourse of applying BK (Counseling Guidance) courses, this aims to convey various information and aspirations, there are various directions of communication in forums that can accommodate every individual in aspiration, and as a venue for socialization of the stakeholders (the government) College and/or student). This is solely for the creation of a synergy and good integrity between the government, universities, and students.

That way, in the end it will form a pattern of relations between policies, habituation, synergies of integrity, goals to be achieved, this will form a neatly arranged behavior pattern. After the pattern is formed, it is necessary to maintain the pattern, so that it can be applied continuously and continuously. As long as it is positive, the pattern formed will also have positive benefits, and with the possibility that the pattern formed will last long. That's how the concept of A.G.I.L might answer this problem.

\section{CONCLUSION}

Teacher Professional Education (PPG) Pre-service is an educational activity to prepare S-1 Education and S-1/Diploma IV graduates who have the talent and interest in becoming teachers to have teacher competencies that are in line with national education standards in Early Childhood Education, Education Basic, and Secondary Education. The foundation underlying PPG is the philosophical foundation, historical foundation, juridical foundation and conceptual foundation. In the PPG program for Bachelor of Education graduates, they need to be given subject areas in the form of subject specific pedagogy (educational field of study) and field experience programs (PPL) education. Whereas in the postgraduate/postIV PPG program Non-education courses are given on 
pedagogic academic competencies, subject areas in the form of subject specific pedagogy (education in the field of study), and teaching exercises or Field Experience Program (PPL). The SM-3T program is a program of education undergraduate service to participate in the acceleration of education development in the 3T area for one year as the preparation of professional educators which will be continued with the Teacher's professional education program. The selection process for SM-3T program participants is conducted in 2 stages, namely national level selection and LPTK selection. The need for information dissemination regarding PPG and SM-3T to students at the Higher Education LPTK. The concept of A.G.I.L from Talcott Parsons needs to be addressed in addressing issues related to PPG and SM-3T where Adaptation, Achievement of goals, Integration, and Maintenance of patterns are needed.

There are still confusion over various discourses regarding both PPG and SM-3T programs, therefore, in this case there is a need for cooperation between the government and educational institutions/LPTKs in introducing the intricacies of the PPG program, both limited to socialization and in the form of additional eyes new lectures in the University curriculum that have LPTKs. This is expected so that students have a view on the steps that will be taken in the future after completing the S1 study period.

There is still a polemic regarding the portion for prospective PPG participants where their competitors are not only from undergraduate students from Education but also for students from Non-Educational Undergraduate Programs. This is felt to be lame because there is an assumption that the PPG program seems to be a short cut for Non-Educational S1 students to become a teacher, which in fact is basically not from prospective education staff but from pure science. Isn't that supposed to have become the main task force for other government fields besides the service that oversees education. The government should be more assertive about this, where related fields and basic must be in harmony with the world of work, and has not become a separate consideration for those who choose departments other than education to the prospects of their work world. It does not necessarily make PPG their mount to become a teacher as if it is a shortcut and this is felt as a form of exclusivity for graduates of Non-Educational S1. Therefore, the implementation of the PPG and SM-3T programs is expected to be wiser and on target.

Perhaps as an input to the government that in implementing the policy it is better to improve and improve existing policies, not by changing leaders, it will also have an impact on policy change and total overhaul, which ultimately is too forced. Because everything that is forced may be less than the maximum result. So, the government needs to invest in every policy that is implemented so that it can be truly maximal in its implementation, so that it hopes to minimize the term victims of government policy. However, after all, the government has tried its best for the realization of equal distribution of education throughout the country with the existence of the SM3T program, and in the future I hope this program will not disappear, only because of the change of leadership, but more to perfection policies relating to programs that already exist and have been implemented. Hopefully education in Indonesia will be more evenly distributed, more advanced, and can be in line with other great nations.

\section{REFERENCES}

[1] Undang-Undang Republik Indonesia Nomor 20 Tahun 2003 Tentang Sistem Pendidikan Nasional (Law of the Republic of Indonesia Number 20 of 2003 concerning the National Education System).

[2] Undang-Undang Republik Indonesia Nomor 14 Tahun 2005 Tentang Guru dan Dosen (Law of the Republic of Indonesia Number 14 of 2005 concerning Teachers and Lecturers).

[3] Peraturan Pemerintah Republik Indonesia Nomor 19 Tahun 2005 Tentang Standar Nasional Pendidikan (Republic of Indonesia Government Regulation Number 19 Year 2005 concerning National Education Standards).

[4] Dani, Irfan. (2012). Diakses dari http://www.sm3tunp.org/2012/03/pengertian.html pada tanggal 24 Mei 2016 pukul 21.30 WIB.

[5] Iskandar. (2009). Metodologi Penelitian Kualitatif. Jakarta: Gaung Persada (GP Press).

[6] Poerwandari, E. K. (2007). Pendekatan Kualitatif dalam Penelitian Perilaku Manusia. Jakarta: Lembaga Pengembangan Sarana Pengukuran dan Pendidikan Psikologi (LPSP3) Fakultas Psikologi Universitas Indonesia.

[7] Moleong, L. J. (2000). Metode Penelitian Kualitatif. Bandung: Rosda Karya.

[8] Moleong, L. J. (2007). Metodologi Penelitian Kualitatif. Bandung: PT Remaja Rosda Karya.

[9] Suprihatiningrum, Jamil. (2013). Guru Profesional: Pedoman Kinerja, Kualifikasi dan Kompetensi Guru. Yogyakarta: Ar-Ruzz Media.

[10] Kompasiana.com, "PPG, Pro-Kontra Bagi Mahasiswa Jurusan Pendidikan”. Online. Dipublikasikan pada 17 Juni 2015.

[11] Ritzer, George. (2012). Teori Sosiologi: Dari Sosiologi Klasik Sampai Perkembangan Terakhir Postmodern. Yogyakarta: Pustaka Pelajar.

[12] Fibrianto, A. S., \& Bakhri, S. (2017). Pelaksanaan Aktivitas Ekstrakurikuler Paskibra (Pasukan Pengibar Bendera) Dalam Pembentukkan Karakter, Moral Dan Sikap Nasionalisme Siswa Sma Negeri 3 Surakarta. Jurnal Moral Kemasyarakatan, 2(2), 75-93. 